\title{
Global Gene Expression Changes by Several Phytochemicals in Human Colorectal Cancer Cell
}

\author{
Min-Hee Park', Eun Hee Kwak', Ho-Yong Sohn², Thomas Eling ${ }^{3}$ and Jong-Sik Kim ${ }^{1}$ \\ ${ }^{1}$ Department of Biological Sciences, ${ }^{2}$ Department of Food and Nutrition, Andong National University, Andong, 760-749, Korea \\ ${ }^{3}$ Laboratory of Molecular Carcinogenesis, National Institute of Environmental Health Sciences, National Institutes of Health, 111 T.W. Alexander \\ Drive, Research Triangle Park, NC 27709, USA
}

Received July 12, 2011 /Revised September 6, 2011 /Accepted September 8, 2011

\begin{abstract}
Phytochemicals, non-nutrient chemicals derived from plants, have been shown to have anti-inflammation, anti-oxidation, and chemopreventive effects. In the current study, we investigated whether five different phytochemicals (resveratrol, genistein, epicatechin gallate, diallyl disulfide, and caffeic acid phenethyl ester) alter cell growth and gene expression in human colorectal cancer HCT116 cells. Using a cell viability assay, we found that each of the phytochemicals tested inhibited HCT116 cell growth in a dose-dependent manner. Additionally, using human oligo DNA microarray analysis, we found that only six genes were commonly up-regulated and seven genes were commonly down-regulated in response to each phytochemical treatment. For the commonly up-regulated genes, the microarray analysis was confirmed by reverse transcription - PCR using gene-specific primers. In addition, NAG-1 protein was up-regulated by all treated phytochemcials. The results of this study may help to enhance our understanding of the general molecular mechanisms of chemoprevention that are mediated by phytochemicals in human colorectal cancer.
\end{abstract}

Key words : Phytochemical, chemoprevention, human colorectal cancer, oligo DNA microarray, gene expression

\section{Introduction}

Colorectal cancer is the third leading cause of new cancer cases as well as cancer deaths regardless of gender in the United States [9]. Despite intensive therapy including surgery, chemotherapy, and radiotherapy, mortality rate related to colorectal cancer was not significantly changed. In this respect, cancer chemoprevention is attractive to prevent cancer development and to retard metastasis of cancer [11]. The most popular cancer preventive agents are non-steroidal anti-inflammatory drugs (NSAIDs), phytochemicals, calcium and vitamins $[14,21,23]$. Among them, phytochemicals have received considerable attention because of availabilities and lacks of side effects.

Phytochemicals are non-nutrient chemicals derived from plant, and has been known to posses many biological functions such as anti-inflammation, anti-oxidation and anti-cancer activities [1]. For this study, we have used five different phytochemicals (resveratrol, genistein, epicatechin gallate, diallyl disulfide, and caffeic acid phenethyl ester).

\footnotetext{
${ }^{*}$ Corresponding author

Tel : +82-54-820-5798, Fax : +82-54-823-1627

E-mail : jsk@andong.ac.kr
}

Resveratrol is a natural compound found in large quantities, most notably in grapes and red wine. Many reports showed that resveratrol induced cell cycle arrest and cell death of human colorectal cancer [8,19]. Our group also reported that resveratrol up-regulated $N A G-1$ (non-steroidal anti-inflammatory drug (NSAID) activated gene-1) expression, which has been shown to be associated with pro-apoptotic and anti-tumorigenic activities, in a p53-dependent manner [3]. Genistein is an isoflavone abundant in soy and induces apoptosis in colon cancer cell [22,28]. Like resveratrol, genistein could induce $N A G-1$ gene in a p53-dependent manner [25]. Epicatechin gallate (ECG) is one of catechin compounds found in green tea. Even EGCG is the most abundant catechin of green tea, ECG was the highest inducer of NAG-1 [4]. Diallyl disulfide is one of compounds in garlic acid and has been shown to induce growth inhibition and apoptosis in several different types of cancer including colorectal, bladder and prostate cancer cells $[10,18,26]$. Caffeic acid phenethyl ester is one of main compounds rich in propolis and induced apoptosis in colorectal cancer and glioma cells $[15,24]$. Even many research groups focused on unveiling working mechanisms of phytochemicals toward cancer chemoprevention, the general working mechanisms still remain 
unclear.

In the present study, we performed oligo DNA microarray and analyzed global gene expression changes induced by phytochemicals treatment. We believe that these results could provide the basis for the understanding of the general molecular mechanism of phytochemicals.

\section{Materials and Methods}

\section{Cell lines and reagents}

Human colorectal cancer cell line HCT116 was purchased from ATCC (Manassas, VA, USA) and maintained in McCoy's 5A medium supplemented with $10 \%$ fetal bovine serum and penicillin-streptomycin. Phytochemicals used were purchased from Calbiochem (San Diego, CA, USA) or Sigma (St. Louis, MO, USA). Antibody to Actin was purchased from Santa Cruz Biotechnology, Inc. (Santa Cruz, CA), whereas NAG-1 antibody was described previously [2].

\section{Chemicals treatment and cell viability assay}

The cell growth of the stable cell lines was measured using the MTS colorimetric assay kit purchased from Promega (Madison, WI, USA). Approximately, $3 \times 10^{3}$ cells were seeded and grown in each well of 96-well plates overnight. Cell viability was measured after $24 \mathrm{hr}$ treatment of each phytochemical at $490 \mathrm{~nm}$ in an ELISA reader plate following the addition of $20 \mu \mathrm{l}$ of MTS solution and incubation at $37^{\circ} \mathrm{C}$ for $4 \mathrm{hr}$.

\section{Microarray analysis}

Oligo DNA microarray experiment was performed by microarray core facility of National Institute of Environmental Health Sciences (NIEHS, USA). Briefly, gene expression analysis was conducted using Agilent human oligo 1A arrays (Agilent Technologies, Palo Alto, CA, USA). Total RNA was amplified using the Agilent Low RNA Input Fluorescent Linear Amplification Kit protocol. For each two color comparison, $750 \mathrm{ng}$ of each Cy3 and Cy5 labeled cRNAs were mixed and fragmented using the Agilent In Situ Hybridization Kit protocol. Hybridizations were performed for $16 \mathrm{hr}$ in a rotating hybridization oven using the Agilent 60-mer oligo DNA microarray processing protocol. Slides were washed as indicated in this protocol and then scanned with an Agilent Scanner. Data was obtained using the Agilent Feature Extraction software (v7.5), using defaults for all parameters. Images and GEML files, including error and p-values, were exported from the Agilent Feature Extraction software and deposited into Rosetta Resolver (version 3.2, build 3.2.2.0.33) (Rosetta Biosoftware, Kirkland, WA). The resultant ratio profiles were combined into ratio experiments as described in Stoughton and Dai [7]. Intensity plots were generated for each ratio experiment and genes were considered "signature genes" if the $p$ value was less than 0.001 .

\section{Reverse transcription-polymerase chain reaction}

Total cellular RNAs were extracted from stable cell lines using TRIzol reagent (GIBCO-BRL, Gaithersburg, MD). Ten micrograms of total RNA was reverse transcribed and a one tenth volume of synthesized cDNA then added to $50 \mu \mathrm{PCR}$ reaction mixture with gene-specific primers and GAPDH primers (Table 1). The thermal cycling conditions used consisted of: initial denaturation at $94^{\circ} \mathrm{C}$ for $4 \mathrm{~min}$, followed by 25 cycles of $94^{\circ} \mathrm{C}$ for $30 \mathrm{sec}, 58^{\circ} \mathrm{C}$ for $30 \mathrm{sec}$ and $72^{\circ} \mathrm{C}$ for $45 \mathrm{sec}$, and final extension for $10 \mathrm{~min}$ at $72^{\circ} \mathrm{C}$. The final PCR products were electrophoresed on a $1 \%$ agarose gel and photographed under UV light.

\section{Western blot analysis}

Cells were collected and lysed in RIPA buffer [50 mM Tris-Cl (pH 8.0), $150 \mathrm{mM} \mathrm{NaCl}, 1 \%$ NP40, 0.1\% SDS, and

Table 1. Gene-specific primer sequences used for RT-PCR

\begin{tabular}{|c|c|c|}
\hline Gene Name & GenBank No & Primer Sequences \\
\hline \multirow{2}{*}{$G A P D H$} & \multirow{2}{*}{ NM_002046 } & Forward 5'-TCAACGGATTTGGTCGTATT-3' \\
\hline & & Reverse 5 '-CTGTGGTCATGAGTCCTTCC-3' \\
\hline \multirow{2}{*}{$N A G-1$} & \multirow{2}{*}{ NM_004864 } & Forward 5'-GGATACTCACGCCAGAAGTG-3' \\
\hline & & Reverse $\quad$ 5'-ATGAGCACCATGGGATTGTA-3' \\
\hline \multirow{2}{*}{$D K K-1$} & \multirow{2}{*}{ NM_012242 } & Forward $\quad 5^{\prime}$-TTCCAACGCTATCAAGAACC-3' \\
\hline & & Reverse $\quad 5^{\prime}$-ATGACCGGAGACAAACAGAA-3' \\
\hline \multirow{2}{*}{$N R 4 A 1$} & \multirow{2}{*}{ NM_173158 } & Forward 5'-GCCTTCTTTTCCTTCAGTCC-3' \\
\hline & & Reverse 5'-GCTGTCTGTTCGGACAACTT-3' \\
\hline \multirow{2}{*}{$G A D D 45 A$} & \multirow{2}{*}{ NM_001924 } & Forward 5'-AGAAGACCGAAAGGATGGAT-3' \\
\hline & & Reverse $\quad 5^{\prime}$-ATGAATGTGGATTCGTCACC-3' \\
\hline
\end{tabular}


$0.5 \%$ sodium deoxycholate]. Thirty micrograms of whole cell extracts were separated in a 4-12\% gel (Invitrogen, Calsbad, $\mathrm{CA})$ and transferred onto a nitrocellulose membrane (Invitrogen, Calsbad, CA). Membranes were blocked in TTBS and 5\% skim milk. Protein bands were probed with primary antibody followed by labeling with horseradish peroxidase-conjugated anti-mouse, or anti-rabbit (Amersham, Piscataway, NJ). Bands were visualized by enhanced chemiluminescence using the ECL kit (Amersham, Piscataway, NJ) according to manufacturer's direction.

\section{Results}

\section{Phytochemicals affect colorectal cancer cell growth}

To investigate the effect of phytochemicals on the growth of colorectal cancer cell, HCT116 cells were treated with five different phytochemicals and sulindac sulfide in different doses. Cells were incubated with 0,25 or $50 \mu \mathrm{M}$ of resveratrol, genistein, epicatechin gallate, diallyl disulfide, whereas cells were incubated with 0,10 or $20 \mu \mathrm{M}$ of caffeic acid phenethyl ester and sulindac sulfide. After $24 \mathrm{hr}$ treatment of phytochemicals, cell proliferation was measured with MTS colorimetric method. As shown in Fig. 1, each phyo- tochemical inhibit cancer cell proliferation in a concentration-dependent manner except ECG. Among phytochemicals, caffeic acid phenethyl ester inhibits cell growth dramatically at even low concentrations compared to other phytochemicals. We determined the concentration of each phytochemical for microarray analysis, based on cell viability assay. We treated $50 \mu \mathrm{M}$ of resveratrol (RES), genistein (GEN), epicatechin gallate (ECG), and diallyl disulfide (DADS), whereas $10 \mu \mathrm{M}$ of caffeic acid phenethyl ester (CAPE) and $5 \mu \mathrm{M}$ (not tested dose in Fig. 1) of sulindac sulfide were treated in HCT116 cells for microarray analysis.

\section{Analysis of gene expression changes by phy- tochemical treatments}

To detect the changes of gene expression induced by phytochemical treatment, we performed human oligo DNA microarray experiment. To begin with, we screened the commonly up-regulated genes and down regulated genes by phytochemicals. The results indicated that only six genes were commonly up-regulated, whereas seven genes were commonly down-regulated (Table 2, 3). Interestingly, most of the commonly up-regulated genes were anti-cancer activity and apoptosis related.

\section{RES}

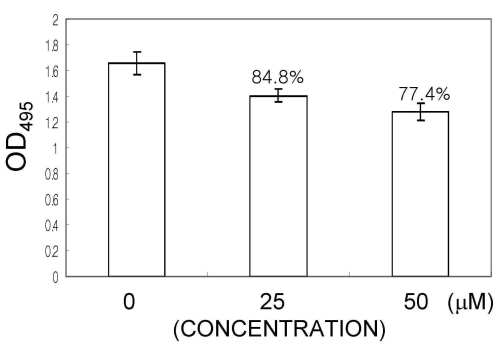

DADS

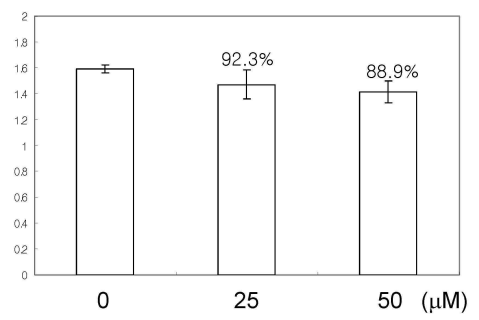

GEN

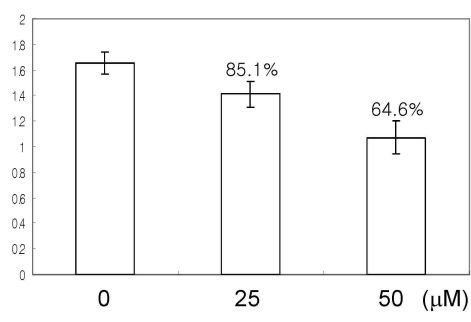

CAPE

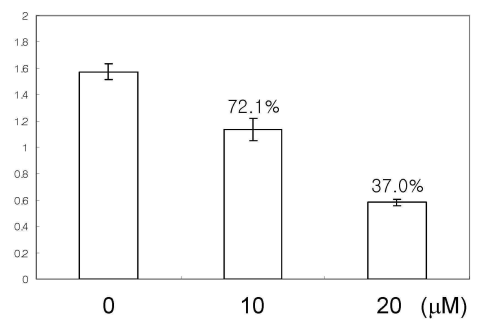

ECG

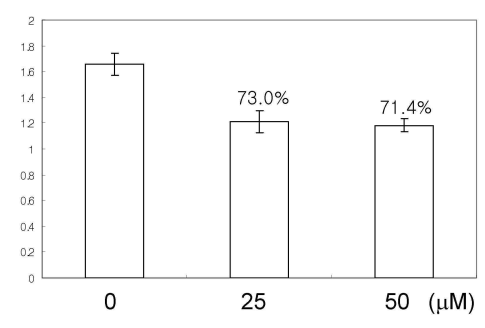

SS

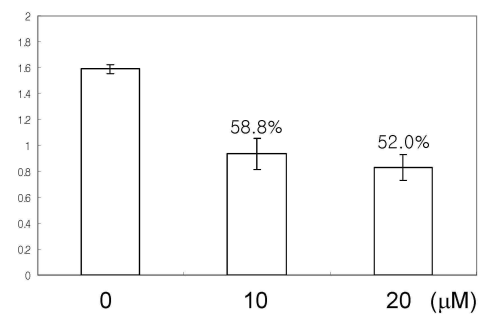

Fig. 1. Effects of phytochemicals and sulindac sulfide on cancer cell growth. HCT116 cells were plated at $3 \times 10^{3}$ cells/well in a 96-well plate and were incubated with either vehicle (DMSO), resveratrol (RES, 25 or $50 \mu \mathrm{M})$, genistein (GEN, 25 or 50 $\mu \mathrm{M})$, epicatechin gallate (ECG, 25 or $50 \mu \mathrm{M}$ ), diallyl disulfide(DADS, 25 or $50 \mu \mathrm{M})$, caffeic acid phenethyl ester (CAPE, 10 or $20 \mu \mathrm{M}$ ) or sulindac sulfide (SS, $10 \mu \mathrm{M}$ ) for $24 \mathrm{hr}$. Cell growth was measured using the MTS cell proliferation kit (Promega, Madison, WI). Values are expressed as mean $\pm \mathrm{SD}$ of 8 replicate experiments. 
Table 2. Commonly up-regulated genes by phytochemicals

\begin{tabular}{cllrrrrrr}
\hline No. & Gene Name & GenBank Acc.No. & RES & GEN & ECG & DADS & CAPE & SS \\
\hline 1 & NAG-1 & NM_004864 & $* 12.59$ & 2.06 & 4.51 & 3.65 & 2.94 & 2.03 \\
2 & DKK-1 & NM_012242 & 7.47 & 5.68 & 2.86 & 2.28 & 1.30 & -1.22 \\
3 & NR4A1 & NM_173158 & 7.13 & 2.09 & 4.38 & 1.54 & 2.13 & $* *$ ND \\
4 & GADD45A & NM_001924 & 2.94 & 1.60 & 2.05 & 1.51 & 1.27 & ND \\
5 & IRF2BP2 & NM_182972 & 2.39 & 1.35 & 2.40 & 1.21 & 1.22 & ND \\
6 & ISG2OL1 & NM_022767 & 1.80 & 1.49 & 2.12 & 1.71 & 1.32 & ND \\
\hline
\end{tabular}

* Arabic numerals: relative ratios, ${ }^{* *} \mathrm{ND}$ : not detected

Table 3. Commonly down-regulated genes by phytochemicals

\begin{tabular}{clllllllc}
\hline No. & Gene Name & GenBank Acc.No. & RES & GEN & ECG & DADS & CAPE & SS \\
\hline 1 & ARHGAP18 & NM_033515 & $*-3.23$ & -1.81 & -1.72 & -1.35 & -1.33 & -1.35 \\
2 & ADMP & NM_145035 & -2.03 & -5.85 & -5.96 & -1.45 & -2.50 & $*$ ND \\
3 & DUSP6 & NM_001946 & -2.02 & -1.53 & -1.73 & -1.42 & -2.50 & -1.42 \\
4 & NIPSNAP1 & NM_003634 & -2.01 & -1.35 & -3.59 & -1.40 & -1.54 & ND \\
5 & DDAH2 & NM_013974 & -1.94 & -1.69 & -1.92 & -1.35 & -1.31 & -1.35 \\
6 & COX15 & NM_004376 & -1.37 & -1.29 & -1.99 & -1.23 & -1.49 & -1.23 \\
7 & LEP & NM_000230 & -1.27 & -1.53 & -2.51 & -1.40 & -1.43 & ND \\
\hline
\end{tabular}

* Arabic numerals: relative ratios, ${ }^{* *} \mathrm{ND}$ : not detected

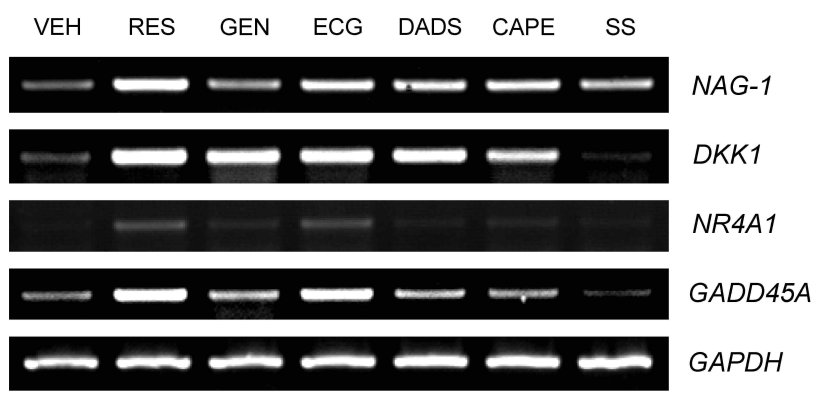

Fig. 2. Gene expression changes by phytochemicals and sulindac sulfide. HCT116 cells were incubated with either (VEH, $0.1 \%$ DMSO), resveratrol (RES, $50 \mu \mathrm{M})$, genistein (GEN, $50 \mu \mathrm{M})$, epicatechin gallate (ECG, $50 \mu \mathrm{M})$, diallyl disulfide (DADS, $50 \mu \mathrm{M}$ ), caffeic acid phenethyl ester (CAPE, $10 \mu \mathrm{M}$ ), or sulindac sulfide (SS, $5 \mu \mathrm{M}$ ) for $24 \mathrm{hr}$. And then, total RNAs were extracted from cells and were subjected to RT-PCR with gene-specific primers.

\section{Microarray data is highly associated with RT-PCR}

Reverse Transcription-PCR was performed with gene specific primers to confirm microarray data. Among commonly up-regulated six genes, 4 genes (NAG-1,DKK-1, NR4A1, and $G A D D 45 A$ ) were selected for RT-PCR, while GAPDH gene was used as a loading control. As shown in Fig. 2, the results indicate that RT-PCR data were exactly associated with microarray data even though $N R 4 A 1$ signal is very weak. And also, we performed Western blot analysis to identify protein expressions for NAG-1. As shown in Fig. 3, the result

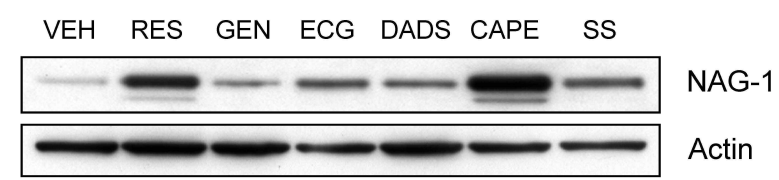

Fig. 3. NAG-1 protein expression in phytochemicals-treated HCT116 cells. HCT116 cells were incubated with either (VEH, 0.1\% DMSO), resveratrol (RES, $50 \mu \mathrm{M})$, genistein (GEN, $50 \mu \mathrm{M})$, epicatechin gallate (ECG, $50 \mu \mathrm{M}$ ), diallyl disulfide (DADS, $50 \mu \mathrm{M}$ ), caffeic acid phenethyl ester (CAPE, $10 \mu \mathrm{M}$ ), or sulindac sulfide (SS, $5 \mu \mathrm{M}$ ) for 24 hr. The cell lysates were prepared and subjected to Western blot analysis using NAG-1 and Actin antibodies.

showed that NAG-1 protein expression is also up-regulated by all treated phytochemicals and sulindac sulfide. Microarray data from those experiments may provide clues to explain molecular mechanisms of cancer chemoprevention by phytochemicals. The characteristics of those genes will be described in the Discussion section.

\section{Discussion}

In this study, we carried out the oligo DNA microarray experiment to identify differentially expressed genes in response to several phytochemicals treatment. From the results, we detected that six genes were commonly up-regulated, whereas seven genes were commonly down-regulated 
by phytochemicals (Table 2, 3). Surprisingly, most of the commonly up-regulated genes were cancer and apoptosis related.

Especially, NAG-1 (NSAID-Activated gene-1), originally discovered by our group, is one of TGF-beta superfamily and has known to be up-regulated by a number of chemopreventive compounds including phytochemicals and cyclooxygenase inhibitors $[5,16]$. In addition, transcriptional regulation of $N A G-1$ by chemopreventive phytochemicals is well defined. Among treated phytochemicals for this paper, resveratol, genistein and diallyl disulfide up-regulate NAG-1 in a p53-dependent manner $[3,13,25]$, whereas epicatechin gallate regulate $N A G-1$ via activating transcription factor 3 (ATF3) [4]. However, NAG-1 regulation by caffeic acid phenethyl ester was not investigated. Among treated phytochemicals, caffeic acid phenethyl ester was the most potent $N A G-1$ inducer in low concentration $(10 \mu \mathrm{M})$. Therefore, further studies to identify the transcription factors and investigate molecular mechanisms of NAG-1 gene regulation by CAPE are needed.

$D K K 1$ is a negative regulator of wnt/beta-catenin signaling because it encodes a secreted protein that binds to LRP5/ 6 and induces its endocytosis. [6,20]. Even though several biological functions of $D K K 1$ have been reported, its expression and regulation were not clearly investigated. Moreover, this is the first report of up-regulation of DKK1 by phytochemicals treatment. We will further investigate DKK1 expression and regulation mechanisms by phytochemicals.

NR4A1 (Nur77, TR3 and NGFI-B), an orphan nuclear receptor, is induced by serum and nerve growth factor. $N R 4 A 1$ has closely related families NR4A2 (Nurr1) and NR4A3 (Nor) and has been known to play a key role for cell survival and apoptosis [17]. However, the expression of $N R 4 A 1$ by phytochemicals has not been reported yet.

$G A D D 45 A$ is one of genes that are induced by DNA damaging agents and is one of transcriptional down-stream targets of p53 [12]. However, GADD45A also can be induced by a p53-independent pathway [27]. Our unpublished data also indicated that GADD45A expressions by phytochemicals were regulated via both ways. Therefore, its regulation mechanism by phytochemicals still remains unclear.

Taken together, phytochemicals have a chemopreventive activity in human colon cancer and modulate the expression of genes such as NAG-1, DKK1, NR4A1 and GADD45A.
However, further studies are needed to determine the relationship between the chemopreventive activities of phytochemicals and over-expression of these genes.

\section{Acknowledgement}

This research was supported by a grant from 2010 International Exchange Program of Andong National University.

\section{References}

1. Andlauer, W., P. Stehle, and P. Furst. 1998. Chemoprevention-a novel approach in diebetics. Curr. Opin. Cin. Nutr. Metab. Care 1, 539-547.

2. Baek, S. J., K. S. Kim, J. B. Nixon, L. C. Wilson, and T. E. Eling. 2001. Cyclooxygenase inhibitors regulate the expression of a TGF-beta superfamily member that has proapoptotic and antitumorigenic activities. Mol. Pharmacol. 59, 901-908.

3. Baek, S. J., L. C. Wilson, and T. E. Eling. 2002. Resveratrol enhances the expression of non-steroidal anti-inflammatory drug-activated gene (NAG-1) by increasing the expression of p53. Carcinogenesis 23, 425-434.

4. Baek, S. J., J. S. Kim, F. R. Jackson, T. E. Eling, M. F. McEntee, and S. H. Lee. 2004. Epicatechin gallate-induced expression of NAG-1 is associated with growth inhibition and apoptosis in colon cancer cells. Carcinogenesis 25, 2425-2432.

5. Baek, S. J., J. S. Kim, S. M. Moore, S. H. Lee, J. Martinez, and T. E. Eling. 2005. Cyclooxygenase inhibitors induce the expression of the tumor suppressor gene EGR-1, which results in the up-regulation of NAG-1, an antitumorigenic protein. Mol. Pharmacol. 67, 356-364.

6. Bafico, A., G. Liu, A. Yaniv, A. Gazit, and S. A. Aaronson. 2001. Novel mechanism of Wnt signaling inhibition mediated by Dickkopf-1 interaction with LRP6/Arrow. Nat. Cell Biol. 3, 683-686.

7. Dai, H., M. Meyer, S. Stepaniants, M. Ziman, and R. Stoughton. 2002. Use of hybridization kinetics for differentiation specific from non-specific binding to oligonucleotide microarrays. Nucleic Acids Res. 30, e86.

8. Delmas, D., P. Passilly-Degrace, B. Jannin, M. Cherkaoui, and N. Latruffe. 2002. Resveratrol, a chemopreventive agent, disrupts the cell cycle control of human SW480 colorectal tumor cells. Int. J. Mol. Med 10, 193-199.

9. Greenlee, R. T., T. Murray, S. Bolden, and P. A. Wingo. 2000. Cancer statistics. 2000 CA Cancer J. Clin. 50, 7-33.

10. Gunadharini, D. N., A. Arunkumar, G. Krishnamoorthy, R. Muthuvel, M. R. Vijayababu, P. Kanaqaraj, N. Srinivasan, M. M. Aruldhas, and J. Arunakaran. 2006. Antiproliferative effect of diallyl disulfide (DADS) on prostate cancer cell line 
LNCaP. Cell Biochem Funct. 24, 407-412.

11. Hawk, E. T., A. Umar, and J. L. Viner. 2004. Colorectal cancer chemoprevention-An overview of the science. Gastroenterology 126, 1423-1447.

12. Jin, S., L. Mazzacurati, X. Zhu, T. Tong, Y. Song, S. Shujuan, K. L. Petrik, B. Rajasekaran, M. Wu, and Q. Zhan. 2003. Gadd45a contributes to p53 stabilization in response to DNA damage. Oncogene 22, 8536-8540.

13. Jr Bottone, F. G., S. J. Baek, J. B. Nixon, and T. E. Eling. 2002. Diallyl disulfide (DADS) induces the antitumorigenic NSAID-activated gene (NAG-1) by a p53-dependent mechanism in human colorectal HCT116 cells. J. Nutr. 132, 773-778.

14. Lamprecht, S. A. and M. Lipkin. 2003. Chemoprevention of colon cancer by calcium, vitamin D and folate: molecular mechanisms. Nat. Rev. Cancer 3, 601-614.

15. Lee, Y. J., H. C. Kuo, C. Y. Chu, C. J. Wang, W. C. Lin, and T. H. Tseng. 2003. Involvement of tumor suppressor protein p53 and p38 MAPK in caffeic acid penethyl ester-induced apoptosis of C6 glioma cells. Biochem Phramacol. 66, 2281-2289.

16. Lee, S. H., J. S. Kim, K. Yamaguchi, T. E. Eling, and S. J. Baek. 2005. Indole-3-carbinol and 3.3'-diindolylmethane induce expression of NAG-1 in a p53-independent manner. Biochem Biophys. Res. Commun. 328, 63-69.

17. Li, Q. X., N. Ke, R. Sundaram, and F. Wong-Staal. 2006. NR4A1, 2, 3-an orphan nuclear hormone receptor family involved in cell apoptosis and carcinogenesis. Histol. Histopathol. 21, 533-540.

18. Lu, H. F., C. C. Sue, C. S. Yu, S. C. Chen, G. W. Chen, and J. G. Chung. 2004. Diallyl disulfide (DADS) induced apoptosis undergo caspase-3 activity in human bladder cancer T24 cells. Food Chem Toxicol. 42, 1543-1552.

19. Mahyer-Roemer, M., A. Katsen, P. Mestres, and K. Roemer. 2001. Resveratrol induces colon tumor cell apoptosis independently of p53 and precede by epithelial differentiation, mitochondrial proliferation and membrane poten- tial collapse. Int. J. Cancer 94, 615-622.

20. Mao, B., W. Wu, G. Davidson, J. Marhold, M. Li, B. M. Mechler, H. Delius, D. Hoppe, P. Stannek, C. Walter, A. Glinka, and C. Niehrs. 2002. Kremen proteins are Dickkopf receptors that regulate $\mathrm{Wnt} /$ beta-catenin signaling. Nature 417, 664-667.

21. Ricchi, P., R. Zarrilli, A. Di Palma, and A. W. Acquaviva. 2003. Nonsteroidal anti-inflammatory drugs in colorectal cancer: from prevention to therapy. Br. J. Cancer 88, 803-807.

22. Salti, G. I., S. Grewal, R. R. Mehta, T. K. Das Gupta, A. W. Jr. Boddie, and A. I. Constantinou. 2000. Genistein induces apoptosis and topoisomerase II-mediated DNA breakage in colon cancer cell. Biochem Biophys. Res. Commun. 36, 796-802.

23. Surh, Y. J. 2003. Cancer chemoprevention with dietary phytochemicals. Nat. Rev. Cancer 3, 768-780.

24. Wang, D., D. B. Xiang, Y. J. He, Z. P. Li, X. H. Wu, J. H. Mou, H. L. Xiao, and O. H. Zhang. 2005. Effect of caffeic aicd penethyl ester on proliferation and apoptosis of colorectal cancer cells in vitro. World J. Gastroenterol. 11, 4008-4012.

25. Wilson, C., S. J. Baek, A. Call, and T. E. Eling. 2003. Nonsteroidal anti-inflammatory drug-activated gene (NAG-1) is induced by genistein through the expression of p53 in colorectal cancer cells. Int. J. Cancer 105, 747-753.

26. Xiao, D., J. T. Pinto, G. G. Gundersen, and I. B. Weinstein. 2005. Effects of a series of organosulfur compounds on mitotic arrest and induction of apoptosis in colon cancer cells. Mol. Cancer Ther. 4, 1388-1398.

27. Yoshida, T., A. Maeda, M. Horinaka, T. Shiraishi, S. Nakata, M. Wakada, S. Yogosawa, and T. Sakai. 2005. Quercetin induces gadd45 expression through a p53-independent pathway. Oncol. Rep. 14, 1299-1303.

28. $\mathrm{Yu}, \mathrm{Z}$., W. Li, and F. Liu. 2004. Inhibition of proliferation and induction of apoptosis by genistein in colon cancer HT-29 cells. Cancer Lett. 215, 159-166. 


\section{초록 : 인간 대장암 세포주에서 파이토케미칼 처리에 의한 유전자 발현 변화}

박민희 ${ }^{1} \cdot$ 곽은희 ${ }^{1} \cdot$ 손호용 ${ }^{2} \cdot$ Thomas Eling $^{3} \cdot$ 김종식 ${ }^{1}$ *

( ${ }^{1}$ 안동대학교 생명과학과, ${ }^{2}$ 안동대학교 식품영양학과, ${ }^{3}$ National Institute of Environmental Health Sciences, National Institutes of Health)

파이토케미칼은 식물유래의 비 영양 성분으로서 항염증, 항산화, 및 화학적 암 예방 등의 생리활성을 가지고 있는 물질이다. 본 연구에서, 우리는 다섯 가지의 다른 파이토케미칼(resveratrol, genistein, epicatechin gallate, diallyl disulfide, caffeic acid phenethyl ester)이 대장암 세포주의 성장과 유전자 발현에 미치는 영향을 연구하였 다. 세포 생존율 연구결과, 처리한 ECG를 제외한 모든 파이토케미칼에 의해 농도의존적으로 세포생존율이 감소 함을 확인하였다. 또한, oligo DNA microarray 실험을 통해 다섯 종류의 파이토케미칼에 의해 공통적으로 증가 되는 유전자 6개와 공통적으로 발현이 감소되는 유전자 7개를 선별하였다. 공통적으로 발현이 증가되는 유전자 를 선택하여 RT-PCR 방법을 통해 발현을 증명하였다. 또한, 파이토케미칼에 의한 NAG-1 단백질의 발현 증가도 확인하였다. 이러한 연구결과는 파이토케미칼에 의해 중재되어 지는 화학적 암 예방법의 일반적인 분자 기전을 이해하는데 도움을 줄 것으로 생각된다. 